\title{
Futures Studies in Finland ${ }^{1}$
}

\author{
Erzsébet Nováky \\ Professor, Department of Futures Studies, Corvinus University of Budapest \\ E-mail: erzsebet.novaky@uni-corvinus.hu
}

\section{Eszter Monda}

PhD Candidate, Department of Futures Studies, Corvinus University of Budapest

E-mail: eszter.monda@stud.uni-corvinus.hu

The development of futures studies and the future-oriented attitude of Finnish institutions and the government can serve as great example for other countries. This attitude appears in education and economy, issues in which Finland is highly competitive in. We introduce the futures studies-related organizations and the foresight system of Finland. An overview of the development of futures studies and the activities, purposes of foresight institutions, with a major emphasis on the Finland Futures Research Centre will be presented. The main question is how could other countries utilize the Finnish example? Societal changes depend on the environment and its historical background, making it quite a challenge to come up with an all-adaptable answer for this question. Thus we will only present guidelines and proposals regarding the development of strategy at the end of this paper.

Keywords: foresight system, futures studies, future-oriented attitude, proposals for strategy JEL-codes: I20

\section{Introduction}

The main purpose of futures studies is to support individual and collective decision-making and enabling a conscious, responsible way of thinking about the future. By using futures

\footnotetext{
${ }^{1}$ Eszter Monda spent two months (August and September 2012) at Turku University to study the activities and results of Finnish futures studies. She enjoyed the assistance and continuous consultations of the colleagues at the Finland Futures Research Centre (further on referred to as FFRC). Olli Hietanen, the Head of Development and the Vice Director of FFRC and permanent expert of the Committee for the Future in the Finnish Parliament, provided a plethora of tremendously useful and highly intriguing materials for our study. Hanna-Kaisa Aalto, the project manager of FFRC, who is also responsible for educational matters, contributed to our study with brilliant ideas and books. The authors are highly grateful to both experts. Furthermore, the hospitality of FFRC assured the best possible circumstances and an inspiring atmosphere, for which both authors are grateful. The research of Eszter Monda at FFRC was financially supported by the Business Informatics Doctoral School of Corvinus University of Budapest, via financial support from the TÁMOP 4.2.2/B-10/1-2010-0023 project, which is gratefully acknowledged. Without the help of the people mentioned above, and the support of the Doctoral School, we would not have been able to complete this study.
} 
studies a complex and creative strategy can be built and developed to support actions and interventions regarding our present systems (Lombardo 2011). Futures studies is a synthesizing field which collects data from two or more disciplines and by combining them intends to create new meanings. Futures studies as a scientific discipline was born in the United States in the 1950s and it started to spread very quickly in Europe, mainly in France. Firstly it was used in the field of military aeronautics in the US, then later in technological forecasting (Masini 1993).

The development of futures studies and the future-oriented attitude of Finnish institutions and the government can serve as great examples for other countries. Finland Futures Research Centre (FFRC) is the biggest academic futures research organization in Finland. This Centre has no match in either the Nordic countries or in Europe. The paper begins with a discussion of the organization of futures studies in Finland.

\section{The organizations of futures studies and foresight system in Finland}

After the stock market collapse and World War II, futures studies became institutionalized as a part of social sciences and political decision making. The RAND (Research and Development) Corporation, the US Army and the Douglas Aircraft Company all played a pioneering role in the development of futures studies. During the 1950s and 1960s, this branch of science strengthened in Europe, especially in France. The degree and speed of development were different in each country, with Finland being a prime example for a positive scenario: the education of futures studies is number one in global rankings, and futures researchers are working in the Parliament. Visionary politics and the foresight system are only two of the multiple factors that ensure the outstanding qualities of Finland, and thus guarantee its leading position among European countries.

Futures studies related organizations that appeared in Finland during the previous decades (Tiihonen 2011) are the following:

- Finnish Society for Futures Studies (1980),

- Parliament's Committee for the Future (1992),

- Turku-based Finland Futures Research Centre (1992),

- Finland Futures Academy network (1998).

From the early 1990s, the mission of Finland was to develop the national foresight system. Some further organizations have been interested and involved in this process: 
- the Academy of Finland,

- Tekes - the Finnish Funding Agency for Technology and Innovation,

- Sitra - the Finnish Innovation Fund,

- units of regional Centres for Economic Development, Transport and the Environment,

- the Regional Council.

The foresight system is characterized by a strong, multiple-leveled structure. The prime ministry gathers data from ministries, the ministries from regional centres, and regional centres from the cities. If the organizations involved in futures studies are looking to analyze something, up-to-date data is delivered at all times by this foresight system.

The participants of the foresight system are shown in the Figure 1. The participants are the following: Regional Council Foresight Networks (RCFNs), Ministries Foresight Networks/Platforms (MFNs), Prime Ministries Office (PMO), the Committee for the Future (CF), the FFRC, the Finland Future Academy (FFA), universities, the Finnish Society for Future (FSF), Finland Futures Research Centre, open foresight companies and Statistics Finland. The largest open foresight companies are Data Ranger (http://www.datarangers.fi/en) and Fountain Park (http://www.fountainpark.fi/en). The four country-specific elements of the Finnish foresight system are highlighted in grey in Figure 1, and are described in more detail in the followign sections.

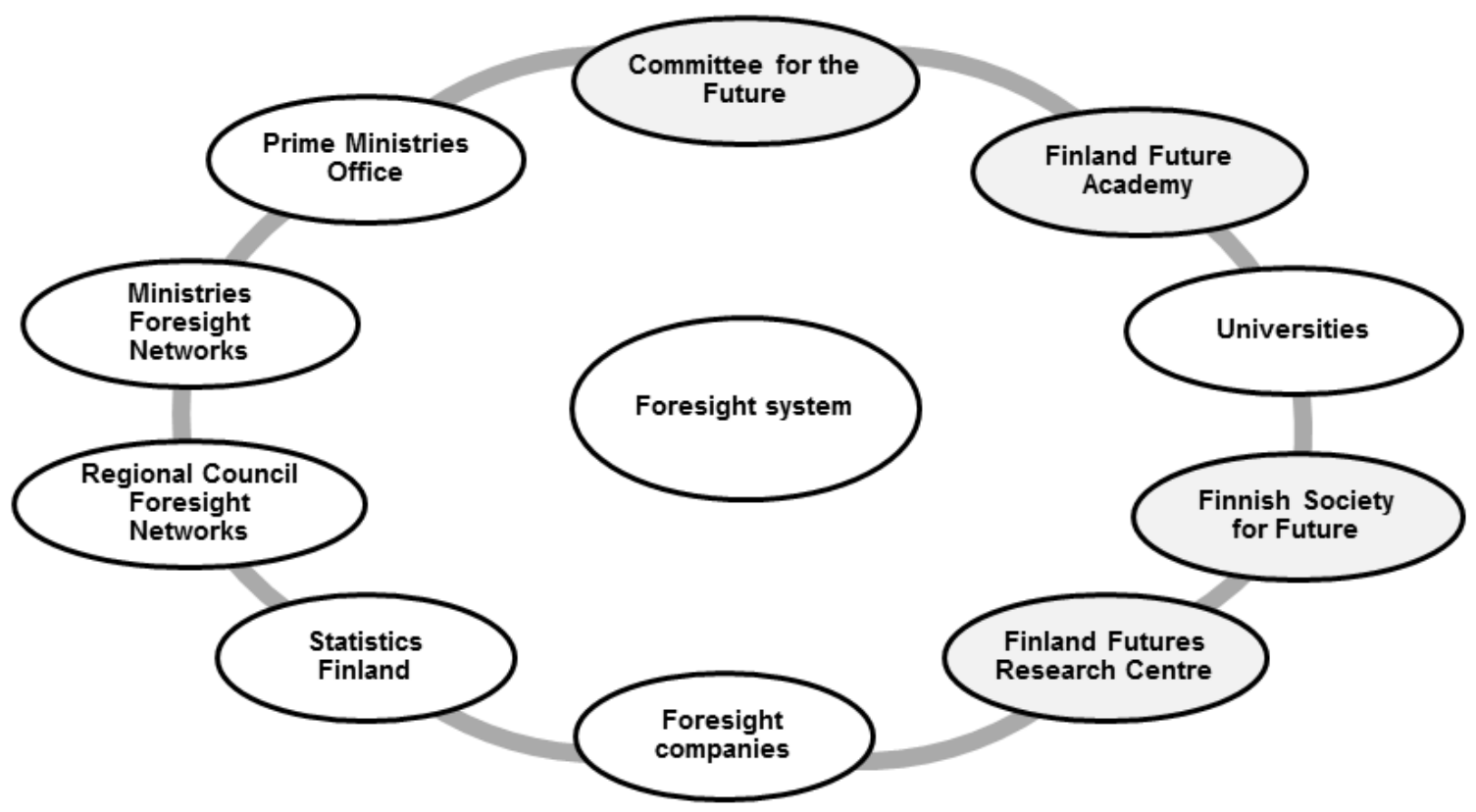

Figure 1. The Finnish foresight system

Source: compilation of the authors 


\subsection{Committee for the Future in the Parliament}

The Committee for the Future was established as a temporary committee in 1992 following the collapse of the Finnish economy. It was the first parlamentary committee in the world dedicated to future-related issues. The influential founding fathers of the Committee were Dr. Eero Paloheimo and Dr. Martti Tiuri (Kuosa 2012: 150). The Committee was granted a permanent status in 1994, and promptly specified its tasks and topics, neither of which has been significantly altered since.

Nowadays, the Committee focuses on making submissions regarding legislative proposals. The Committee contributed to legislative matters of high importance such as new universities, applications for licences to build nuclear power plants, legislation on the production of genetically modified plants. The Committee should, once in each parliamentary term, conduct a general exploration of the state of Finland, including the related scenarios and or futures map. "A sum of Eur 73000 has been set aside for 2011, in addition to which Eur 5000 per month has been granted to cover the salary of a special expert" (Tiihonen 2011: 4). This expert is appointed by the FFRC.

The essence of the task of the Committee for the Future does not lie in creating legislative proposals, but rather in examining and overseeing the opportunities, threats, and weak signals related to the future. It has an opinion-shaping role, and the Finnish society is in need of such services to prepare for the future. For the current (2011-15) parliamentary term, the Committee concentrated on direct democracy, new communications, and developing participatory operational models. They have participated in the activities of other international linkage institutions, including the EPTA (European Parliamentary Technology Assessment) in Brussels and in the French Parliament. Six reports on the future have been submitted:

- Report on the Long-Term Future (1993);

- Part I Finland and the Future of Europe (1996);

- Part II Honest and Courageous - a Finland of Responsibility and Confidence (1997);

- A Finland of Balanced Development 2015 (2001);

- A good Society for People of All Ages, a report on demographic development, demographic policy and preparation for a changing age structure (2004) and

- Towards a Finland of Low Emissions, a report on climate and energy policy (2009). 
During the 2011-15 parliamentary term, the Committee focuses on four areas: sustainable growth, an inspired society, acquiring new knowledge, and the endurance of the welfare society. The analysis of the first three areas consists of three parts: (1) choosing the best practices, (2) analysing these practices, and (3) recommending measures according to results of the analysis. To reach the desired goals, the Committee cooperates with other sectors. In the case of growth and inspired society, companies and entrepreneurs participate in the process, while in the case of new knowledge, educational institutions will serve as the contributors. The project entitled "Can the Welfare Society Endure?" will be implemented in four stages. The first stage will contain the view of experts on the causes and consequences of modern well-being and malaise. In the second part, these experts will analyze the latest studies in connection with the most crucial topics. In the third part, a model of welfare in a Finland of the future will be created with the aid of participatory methods. In the last stage, a proposal will be given for measures. (Eduskunta, Parliament of Finland: The Committee for the Future 2012). Because of our focus, we mainly enumerated the research topics which prove actuality and innovation.

Figure 2 shows the visionary dialogue between the Government and the Parliament. The Finnish Parliament was founded in 1917. We have to mention that Finland is considered to be the pioneering European country in allowing women to have unrestricted rights to both voting and standing for Parliament. This was granted in 1906. One of the Parliament's Committee is the Committee for the Future which has permanent experts to deal with futuresrelated matters by applying futures studies including their methodology. Every government, once per each parliamentary term, produces a Futures Report. When the government presents its Futures Report, the Parliament - with the coordination of the Committee for the Future comes up with a reply. A governmental term is 4 years which means there is one Futures Report in every 4 years. The Committee cooperates with other stakeholders (companies, universities, and citizens). It employs a large number of futures studies methods, one of them being the participatory method. This report is compiled by the Committee and the government with the participation of the society. These two reports (The Future Report of the Government and The Future Report of the Parliament) establish a sort of visionary base for the next government, which schemes up its program with respect to both its preferences and the conclusions of the futures reports. 


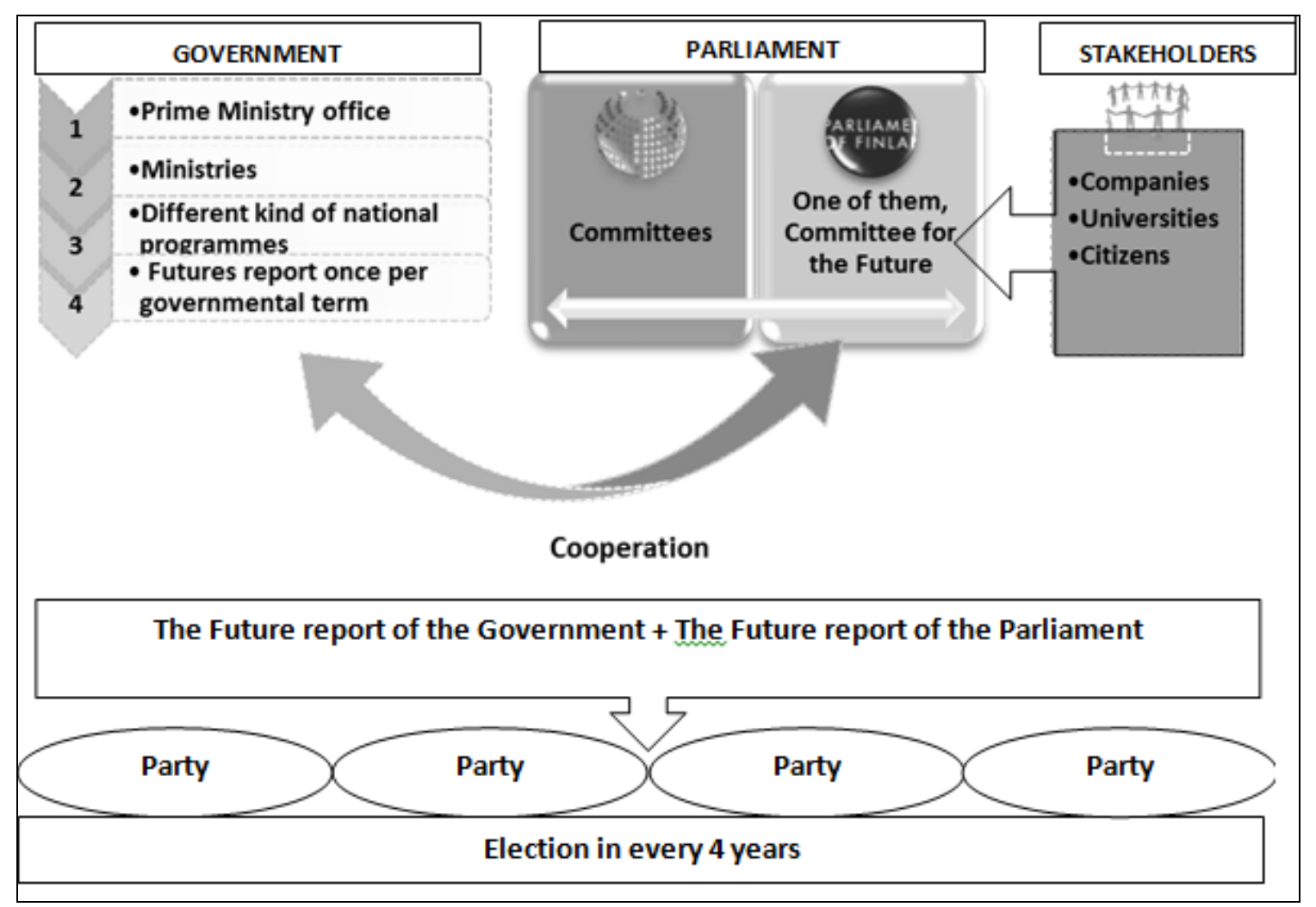

Figure 2. Committee for the Future

Source: compilation of the authors

The Committee has connections with the FFRC and many universities. Their publications are available on the internet (The Finnish Parliament 2012) mainly in English about many important topics, such as Democracy and Futures (Mannermaa et al. 2006). This study was made as a result of an international cooperation by futurists of many countries (USA, Canada, Russia, Italy, France, Germany, Pakistan-Australia, Japan, Hungary (Nováky - Kappéter 2006), Korea, Finland) over the world (Mika et al. 2006).

\subsection{Finland Futures Academy (FFA)}

The Finland Futures Academy, coordinated by the FFRC, is a national network of universities providing academic education and research programmes in futures studies. The following nine universities constitute the FFA:
1. University of Aalto:
2. University of Helsinki
3. University of Lapland
4. Lappeenranta University of Technology
5. University of Oulu
6. Tampere University of Technology
7. University of Tampere
8. University of Turku
9. Åbo Akademi University 
The FFA's study module is offered in member universities throughout Finland. They train futures-oriented experts through academic education for both undergraduate and postgraduate students. A variety of programs are available: Master's Degree Program in Futures Studies, MSc in Strategic Innovation and Future Creation, Multidisciplinary Sustainable Development. The Master's Program is available from 2004, the Doctoral Program from 2005, and the International Master's Program from 2007. The impressive numbers prove how strong Finnish futures studies are in education. More than 6000 participants, and more than 4 000 lecturers were involved in the courses, resulting in more than 20000 credits until the end of 2011 .

\subsection{Finnish Society for Futures Studies}

The Finnish Society for Futures Studies was established in 1980 on the recommendation of the Government's Central Board of Research Councils. Fourteen Finnish institutions of higher education were among the founding members, and 14 additional institutions and over 700 individuals have since joined the society. The Finnish Society for Futures Studies aims to influence the long-term development of Finnish society by advancing futures research and its utilization. The society has been keenly interested in the activities of the Club of Rome. It is the member of the World Futures Studies Federation and the World Future Society (Futuresociety 2012).

\subsection{Finland Futures Research Centre}

The Finland Futures Research Centre (FFRC) belongs to the Turku University. University of Turku was founded in 1920. "The University promotes the development of the surrounding community, and especially that of its own region, Southwest Finland. In collaboration with the region's other institutions of higher education, the University promotes the Turku region as a centre of high-quality education, research and innovation." (Turku University website 2012) The new University of Turku, established on $1^{\text {st }}$ January 2010 , when the University of Turku and the Turku School of Economics were merged, is an internationally competitive research university with its operation based on high-level multidisciplinary research. The mission of the University is to promote free research and scientific knowledge and to provide quality research-based education.

The FFRC is a multidisclipinary academic organization focusing on research, training, and development. It was established in 1992, and now functions as a special unit of the 
University of Turku focusing on futures studies and foresight. The Centre operates offices in Turku, Helsinki, and Tampere, and in the capital of Laos, Vientiane. The approximately 50 colleagues of the Vientiane office mainly deal with the promotion of the transition of sustainable energy in their region through collaboration and networking, research and capacity building (FFRC Mekong homepage 2012). In 2011, researchers at the Centre carried out nearly 60 research- and development projects (see Appendix A.1 and A.2). The turnover was around 3.8 million euros in 2011 (see Appendix A.3). During the course of the last few years, both the turnover and the number of employees have increased, while the number of projects has decreased, since the Centre wanted to concentrate its resources.

FFRC boasts a widespread, multidisciplinary network both nationally and internationally. Their repertoire of researches is versatile, especially in the following eight fields: future of environment and energy, consumption, education and learning, media and communications, safety, socio-cultural phenomena, regional development and foresight, sustainable development and responsible business. Among the topics mentioned above, consumption and media are the largest projects. The Centre publishes its own series of publications both online and in print, including 15-20 scientific articles and reports annually (FFRC website and brochure 2012). The group of experts at FFRC has a colorful line-up, being made up biologists, physicists, sociologists, economists, ethnographers and geographers.

In our opinion, not only its significance and history are what make the Centre intriguing, but also the research questions, the methodology, the approach, the vast amount of publications, the projects, and the results, which are all of great help to experts of similar fields, and hopefully to professionals of other fields.

\subsubsection{The research questions of FFRC}

The mission of FFRC concentrates on a pair of crucial matters: creating sustainability and laying the foundations of human well-being. The reason behind the emphasis on sustainability is that the founder of FFRC - Prof. Pentti Malaska -was the member of the Club of Rome, an organization focusing on sustainable growth. Since the task of futures studies is to outline alternative futures for stakeholders, the FFRC deals with matters which state critical problems to be solved regarding the fate of humanity. The trends are the socalled drivers, for instance information society, forest industry, bio-age, etc. (Hietanen Ahvenainen 2012), (Wilenius - Kurki 2012). The FFRC aims to find solutions for these trends, and, during the process, more issues are defined which could potentially serve as 
solutions. The most major trends are the information society, the lack of resources, creative economy and media, growing consumption, and bio-age. The chronological order is demonstrated in the Figure 3, top-down. The Centre aims to solve these trends by accomplishing its mission (i.e. sustainability for welfare society). The dealing with the future of the environment has remained an important topic, and it is today perhaps more important than ever. We can see this trend in the publications of FFRC as well, for example climate change (Juhola et al. 2013), integrated water resources management (Jusi 2013), sustainable society (Kaivo-oja et al. 2013) renewable energy development (Luukkanen et al. 2013), (Tapio et al. 2013), future of food (Kirveennummi - Mäkelä - Riikka 2013). Many FFRC ebook publications are in connection with energy (Tuominen et al. 2013; Heinonen Ruotsalainen 2013a) and climate change (Käkönen et al. 2013). Other earlier mentioned topics are relevant nowadays as the scenario analyses of the futures of journalism profession (Kaivo-oja 2013) and eco-innovation (Karjalainen et al. 2013) in the category of creative media and economy. Methodological techniques have always belonged among the interests of FFRC as FFRC uses and creates techniques. The Futures Clinique is a distinctive participatory and exploratory futures workshop technique which was created by FFRC (Heinonen - Ruotsalainen 2013b).

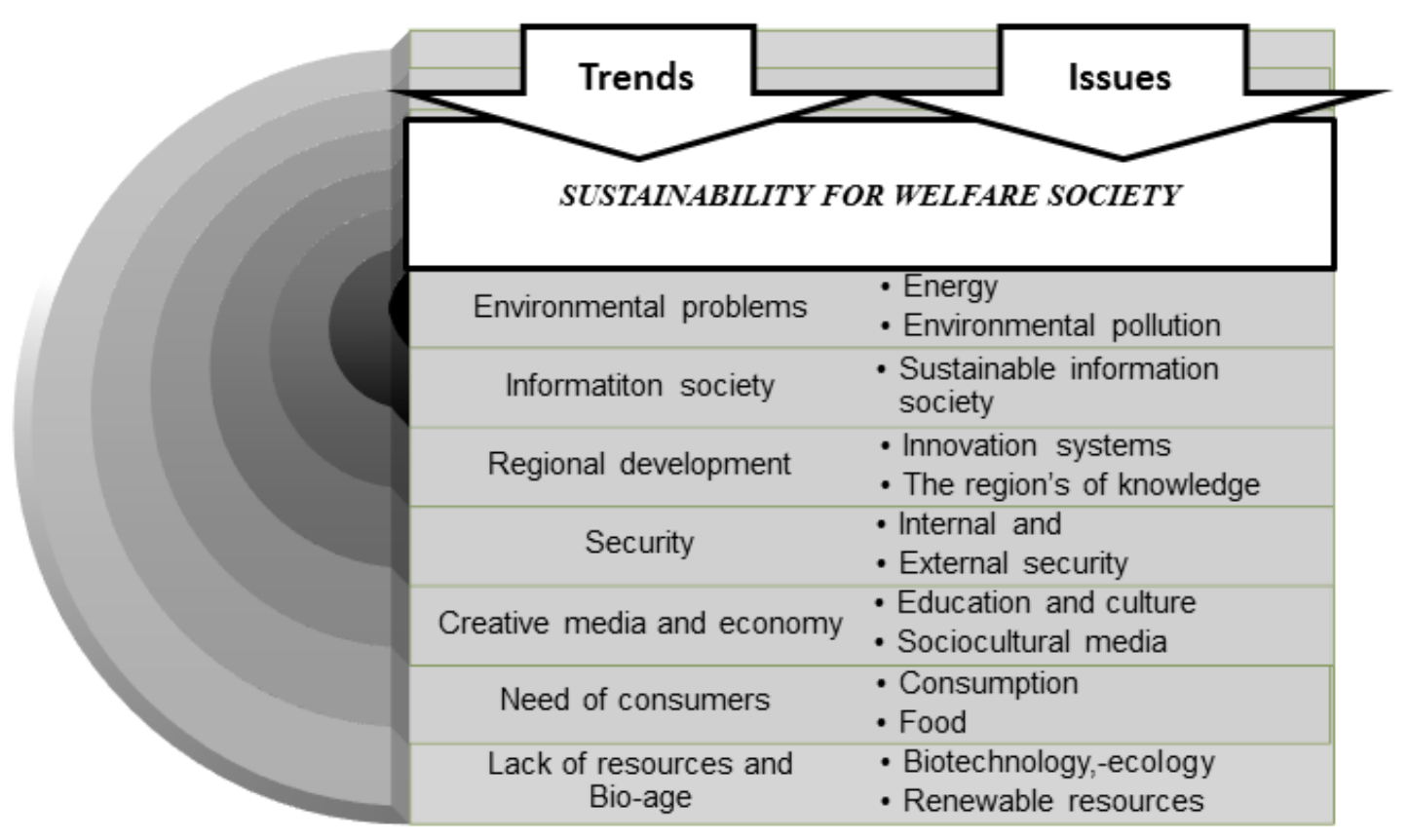

Figure 3. The research interest of FFRC

Source: compilation of the authors 


\subsubsection{Communication and values}

The FFRC has three determining principles:

1. Pentti Malaska, the founding member laid down the first principle: If you do something, do it with fun! It means that the personnel of the FFRC should search for projects according to their interests.

2. The second is the belief invested in the network. They work as a team. Half of the team is made up of the employees of the FFRC, while the other half of exterior contributors. They are constantly building new connections, which makes it easier to call experts from foreign countries in case of an international project. These connections are not solely based on financial interests, since the FFRC is well aware of the fact that fruitful cooperations are more important than income.

3. The third principle is freedom. The employees know their deadlines, tasks, and the framework of the project they are involved in, thus they can work flexibly.

\subsubsection{The methods of FFRC}

Initially, the research methods were trend extrapolation, data collection, and philosophical discussion, a mixture of statistical methods and futures thinking. Later on, because of Osmo Kuusi, an expert in social sciences, the Delphi method was applied. After that, systems thinking and futures workshop took over, on account of Anita Rubin, an expert in soft systems methodology and in the modelling of society. Next up were participatory methodologies, CLA (Casual Layered Analysis), and learning via games. The new typology of paradigms of futures studies was described with specific focus on decision-making by Olli Hietanen and Petri Tapio (Hietanen - Tapio 2002). Naturally, several other futures studies methods were put into practice, with scenario building, futures wheel, and futures table being prime examples. The newest methods are visionary transformation and network management to find alternative ways of solutions (Green Elephant Hunting). Reality checking is less emphasized due to the foresight system described earlier.

\subsubsection{FFRC projects}

The FFRC has about 60 projects per year in connection with other fields. The main topics of the FFRC are the following: the future of information society, energy, regional development, and innovation systems (EU), security, society, creative economy and media (education and culture), infrastucture, consumption (food), bio (FFRC inner brochure 2012). 
The FUTU project was one of the largest projects of FFRC. Ten papers were published as the result of the project. Ten researchers and its leader, Prof. Pentti Malaska worked on the project. Within the FUTU project three studies were writtin on citizenship and eco-modernization in the information society. The first study was "Sustainable Technology Sustainability of what?", which is about the connection of sustainability and techno-optimism and techno-pessimism approaches (Mettler 1997). The second study was about the "Transforming modern representative democracy via advanced telecommunications", focusing on the development of teledemocracy globally and a new democratic political communications systems (which includes televoting, deliberative polling, electronic town meetings) (Becker - Slaton 1997). The third study was about "Participatory democracy and Civil society - transforming societal decision making in the information age". This paper recognized that there are many possibilities to extend democracy and to give citizens a feeling that they are really involved in the decision-making process (Keskinen 1998).

The base funding provided by the University constitutes $22.8 \%$ of the turnover. The FFRC has multiple supporters, as well as external funders: the government $(21.6 \%)$, the European Union (16.8\%), the Academy of Finland (14.7\%), etc. (see Appendix A.4) according to the turnover data for 2011.

\section{Conclusions}

The study summarized the role of futures studies in Finland and the importance of the FFRC. The question is how could other countries utilize the thought process of Finland? Societal changes depend on the environment and its historical background, and the connections and qualities of the stakeholders and the framework they exist in. Each country has a different history, a different environment, a different structure, and different actors, although all actors have influence. It is quite a challenge to come up with an all-adaptable answer for the former question, thus we will only present guidelines regarding the development of strategy based on the example of Finland, and mainly on that of the FFRC.

The Finnish society has excellent qualities: competitive ability and creativity, wellbeing of the local culture, know-how and process management related to education and health care. The developments on the future depend on the combination of creative economy and information society. Concerning digital development and future-oriented thinking, Finland holds the leading position among the countries of the European Union. The government used its vast power to introduce the changes and to influence the actors. Its behavior is proactive, 
and its thinking is long term-oriented. The former attribute is reflected by the development of futures studies, the institutions of futures studies, and the support of education. The visionary politics and the foresight system of Finland make it easier to find solutions.

The proactive, solution-oriented Finnish mentality supports the well-functioning process management in which Finland is a pioneer. The strong futures studies education has an influential role in multiple fields. FFRC's courses are available in Finland and around the world. In 2012 and earlier as well, Corvinus University of Budapest in Hungary, Tamkang University in Taiwan and the University of Alicante in Spain were the foreign partner universities of the FFA. They had different roles in implementing the course "Futures 1: How Can We Explore the Future?" (Aalto et al. 2012:12-13). This course was led by Eszter Monda, at Corvinus. Earlier, similar Finnish-inspired courses were led and organized by Réka Várnagy, Bernadett Szél and Helga Veigl with their huge professional experience and empathy. They took part in the evaluation of group assignments of courses as well. The Hungarian students participated enthusiasticly in the interactive learning process.

In Hungary futures studies are not represented strongly the level of bachelor, master or doctoral studies. There are futures studies related courses at Corvinus University of Budapest, Budapest University of Technology and Economics, Miskolc University, and the University of Pécs. Doctoral level training with futures studies specialization only exists at Corvinus University of Budapest since 2009.

The Hungarian students are motivated and active during futures studies courses. They participated in the annual competition of Association of Professional Futurists many times where they achieved ranked results. As we described earlier in our study, students of Corvinus University attended Finnish online courses. We see the interest and active attendance of students in this field of science which is promising.

It is perceptible from the media, the national anthem and general life in Hungary that the Hungarian nation looks often into the past, instead of looking into the future. In the last 15 years future orientation did not develop sufficiently (Hideg - Nováky 2008). The study entitled "Hungary 2025" showed an increasing number of youth who imagine their carrier abroad at least temporarily (Nováky 2010). Perhaps this situation is connected to the fact that there are no futures studies oriented committee or political units in the Hungarian Parliament.

The Finnish government deals with the most important issues and pays extra attention to the new tasks, issues, and hardships of society. The programmes aimed at finding new solutions came to life through the cooperation of different sectors. The qualities of Finnish thinking lead us to a prosperous environment where futures studies are acknowledged not just 
in science, but in supporting decision-making processes in Parliament. These qualities are the followings: visionary politics and foresight system, future-oriented thinking, proactivity, strong cooperation within the society, solution-oriented, long-run thinking.

In conclusion of our study, five proposals are defined according to FFRC's most definitive qualities which can help us, the Hungarian futurists, to prepare effectively for changes and create better strategy.

\section{Proposal 1: Adapt to the changes, be pliant and flexible}

One of the pillars of the strategy of FFRC is fast reaction to changes, and it has no multiple year-long plans in that regard. Nevertheless, its vision is well thought-out, is flexible, and the organization is constantly studying its environment in search of new possibilities. Why is this is a good strategy is illuminated by the following quote from Charles Darwin: "It is not the strongest of the species that survives, nor the most intelligent, but the one most responsive to change." So the one who adapts has a better chance of staying alive. An adaptive individual is someone capable of steering the mind in new directions, and is able to make choices based on desired goals. Human nature might constitute a roadblock, since it tends to create habits, to think in patterns, and to stay in its comfort zone. The only way out is to develop one's skills, to adapt to changes, and to invest extra energy into the effort aimed at steering the changes in the direction of one's goals. The essential skills of adapting and being flexible to changes are having a clear vision of the mission, continuous self-improvement, lifelong learning, a higher level of personal and professional achievement. When somebody wants to change something in their lives, they have to understand the nature of change. The first step begins with the change in our thinking and our beliefs, and only then can we change our behavior.

\section{Proposal 2: Be proactive and motivated by an inner drive}

The employees of FFRC search for projects according to their personal research interests. This is the best catalyzer of inner motivation. Motivation can come either from the outside or the inside. External motivation derives from fear or reward, but inner motivation is always the strongest driving force. They act proactively and do not wait for possibilities, they create the possibilities. They are responsible for finding new projects. In case they do not find one, their income will decrease. 
They are result-oriented. They know the deadline and the duties, but they can decide where, when, and who they want to work with. This results in freedom, independence, responsibility, and creates a solid foundation for creativity. They have a widespread network of national and international connections, which ensures safety for the continuous work. FFRC is open for opinions and suggestions of futurists of other countries, therefore FFRC invited an International Advisory Board of renowned futurists from European and non-European countries (members include Eleanora Masini, Erzsebet Novaky, Jerome G. Glenn, Karlheinz Steinmueller (new chair), Pentti Malaska, Sari Söderlund and Juha Kaskinen) to support its scientific and educational work (Kaskinen 2005). The board helped the work of FFRC effectively during its operation between 2001 and 2010.

Proposal 4: Work in a versatile group representing divers interests, and use various methods In the section presenting FFRC projects, we described how many projects and areas of interest the FFRC has. This "more than one pillar" strategy means that the turnover derives from several sectors and institutions, and guarantees that they will have enough work in the future. The research of FFRC concerns a vast amount of problems that need to be solved, which necessitate using several futures studies methods.

\section{Proposal 5: Apply participatory methods for solving up-to-date problems}

The FFRC focuses on the most burning issues and long-term thinking, while also dealing with up-to-date topics. In order to solve these problems, participatory methods are preferred. The opinions of the actors and society are of high importance in finding the right solutions.

Can the above mentioned qualities and proposals work in Hungary or in other countries? Our answer is yes, undoubtedly. Maybe these qualities need to be altered when inserted into a different context, but a combination of them can help in building a better strategy. And if they can, why is it so? Because they are the guiding lights that lead us on the way to fulfilling our vision. It is our unspoken human obligation to shape a better future. In Hungary there are many results within the theoretical-methodological development of futures studies and its applied experience too, but our country would be in a better position by applying the Finnish science and research related organizational mentality and experience. In the light of the present situation we recommend preparation for the changing world and thinking in alternatives. Futhermore we recommend strengthening the teaching of futures studies in 
courses and specializations. The role of future oriented thinking would be profitable in building strategy and decision-making on political level, too.

\section{References}

Aalto, H.-K. - Miettinen, S. - Mäki, M. - Söderlund, S. (ed.) (2012): Pentti Malaska In Memoriam. Finland Futures Academy, Futures Academy Annual Report. University of Turku.

Becker, T. - Slaton, C. D. (1997): Transforming modern representative democracy via advanced telecommunications. Turku School of Economics and Business Administration and Finland Futures Research Centre, FUTU publication 7/97.

Eduskunta, Parliament of Finland: The Committee for the Future (2012): The Comittee for the Future's vision, strategy and operational plan for 2011-15, $14 \mathrm{p}$.

FFRC inner brochure (2012): Finland Futures Research Centre - opening opportunities

FFRC Mekong homepage (2012): Research and Capacity - Building in the Mekong Region. http://www.mekong.fi/, accessed 27/11/2014.

FFRC website (2012): Wireless well-being in Southwest Finland. http://ffrc.utu.fi/en/research/projects/southwestICT/wsis_e.pdf, accessed 27/11/2014.

Futuresociety (2012): The Finnish Society for Futures Studies. http://www.futurasociety.fi/tts english.htm, accessed 27/11/2014.

Heinonen, S. - Ruotsalainen, J. (2013a): Energy Futures 2030. Toward the Neo-Growth paradigm of the Sixth-Wave Era. FFRC eBook 1/2013, Finland Futures Research Centre, University of Turku.

Heinonen, S. - Ruotsalainen, J. (2013b): Futures Clinique - Method for Promoting Futures Learning and Provoking Radical Futures. European Journal of Foresight Research 1(7): $1-11$.

Hideg, É. - Nováky, E. (2008): A jövőhöz való viszony és változása Magyarországon [The attitude toward future and its change in Hungary]. Magyar Tudomány 9: 1125-1135.

Hietanen, O. - Ahvenainen, M. (2012): Bio Age 2100. The Futurist 46(5):

Hietanen, O. - Tapio, P. (2002): Epistemology and public policy: using a new typology to analyse the paradigm shift in Finnish transport futures studies. Futures 34(7): 597-620.

Juhola, S. - Peltonen, L. - Niemi, P. - Vehmas, J. (2013): Exploring mitigative and response capacities to climate change in European regions. In: Schmidt-Thome, P. - Greiving, S. 
(ed.) European Climate Vulnerabilities and Adaptation: A Spatial Planning Perspective, Wiley-Blackwell: Chichester. 131-146.

Jusi, S. (2013): Integrated Water Resources Management (IWRM) Approach in Water Governance in Lao PDR: Cases of Hydropower and Irrigation. Dissertation for the degree of Doctor of Administrative Sciences. Acta Universitatis Tamperensis 1820. Tampere: Tampere University Press, 228 p.

Kaivo-oja, J. (2013): Scenario Analyses of the Futures of Journalism Profession. Journal of Futures Studies 18(2): 59-82.

Kaivo-oja, J. - Panula-Ontto, J. - Luukkanen, J. - Vehmas, J. (2013): Relationships of the dimensions of sustainability as measured by the Sustainable Society Index framework. International Journal of Sustainable Development and World Ecology 21(1): 39-45.

Karjalainen, A. - Vehmas, J. - Lauttamäki, V. - Keto, S. - Quynh Trang Dihn, T. Doranova, A. - Fischer, S. - Burrel, L. (2013): From Challenges to Business Opportunities. Eco-innovation Observatory Foresight Report 72.

Kaskinen, J. (2005): Helsinki Node Report July 2004 - March 2005. http://www.millenniumproject.org/millennium/mppc-0405/Helsinki-0405.pdf, accessed 27/11/2014.

Käkönen, M. - Karhunmaa, K. - Bruun, O. - Kaisti, H. - Tuominen, V. - Thuon, T. Luukkanen, J. (2013): Climate Mitigation in the Least Carbon Emitting Countries. Dilemmas of Co-benefits in Cambodia and Laos. FFRC eBook 3/2013. Finland Futures Research Centre, University of Turku.

Keskinen, A. (1998): Participatory democracy and Civil society - transforming societal decision making in the information age, Futu-publication 1/98. Turku School of Economics and Business Administration and Finland Futures Research Centre.

Kirveennummi, A. - Mäkelä, J. - Riikka S. (2013): Beating unsustainability with eating: four alternative food-consumption scenarios. Sustainability: Science, Practive and Policy, 9(2). Kuosa, T. (2012): The Evolution of Strategic Foresight. Navigating Public Policy Making. Gower Publisher.

Lombardo, T. (2011): Creativity, Wisdom, and Our Evolutionary Future. Journal of Futures Studies 16(1): 19-46.

Luukkanen, J. - Akgün, O. - Pasanen, T. - Keskiväli, I. - Panula-Ontto, J. - Kaivo-oja, J. Tuominen, V. - Vehmas, J. - Lakkala, H. (2013): Energy Dependence and Potential for Renewables. Analysis of Future Trends and Potentials for Renewable Energy Development in Cambodia and Laos. In: Sudhakara Reddy, B. - Ulgiati S. (eds.): Energy 
Security and Development- The Changing Global Context. Cambridge Scholars Publishing.

Mannermaa, M. - Dator, J. - Tiihonen, P. (ed) (2006): Democracy and Futures. Publication of the Committee for the Future, Parliament of Finland.

Masini, E. B. (1993): Why Futures Studies? London: Grey Seal.

Mettler, P. H. (1997): Sustainable Technology - Sustainability of what? FUTU publication 3/97, Turku School of Economics and Business Administration and Finland Futures Research Centre.

Nováky, E. - Kappéter, I. (2006): Futurists as Pionieers in Handling Participativity and Aggression in a Post-Socialist Democracy. In: Mannermaa, M. - Dator, J. - Tiihonen, P. (eds): Democracy and futures. Publication of the Committee for the Future. Parliament of Finland, pp. 170-179.

Nováky, E. (2010): Magyarország 2025 [Hungary 2025]. Budapest: Gazdasági és Szociális Tanács.

Tapio, P. - Varho, V. - Heino, H. (2013): Renewable energy in the Baltic Sea region. Journal of East-West Business 19(1-2): 47-62.

The Finnish Parliament (2012): The Committee for the Future. http://web.eduskunta.fi/Resource.phx/parliament/committees/future.htx, $27 / 11 / 2014$.

Tiihonen, P. (2011): Revamping the work of the Committee for the Future. Committee for the Future, 7/2011.

Turku University website (2012): History. http://ffrc/en/university/history/, accessed $27 / 11 / 2014$.

Tuominen, V. - Pasanen, T. - Keskiväli, I. - Lakkala, H. - Akgün, O. - Luukkanen, J., Kaivo-oja, J. - Panula-Ontto, J. (2013): Energy, Environment and Livelihoods in the Lao PDR. Results from a 2011 Household Survey. FFRC eBook 5/2013, Finland Futures Research Centre, University of Turku.

Wilenius, M. - Kurki, S. (2012): Finland and the emergence of Bio-age. In: Surfing the Sixth Wave. Exploring the next 40 years of global change. FFRC eBook 10/2012, Finland Futures Research Centre, University of Turku.

\section{Appendix}




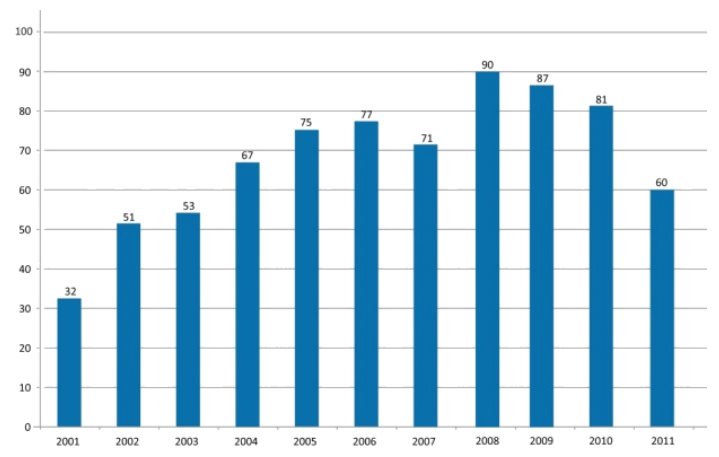

Figure A.1. Number of FFRC projects

Source: FFRC website, available at: http://ffrc.utu.fi/en/about/figures

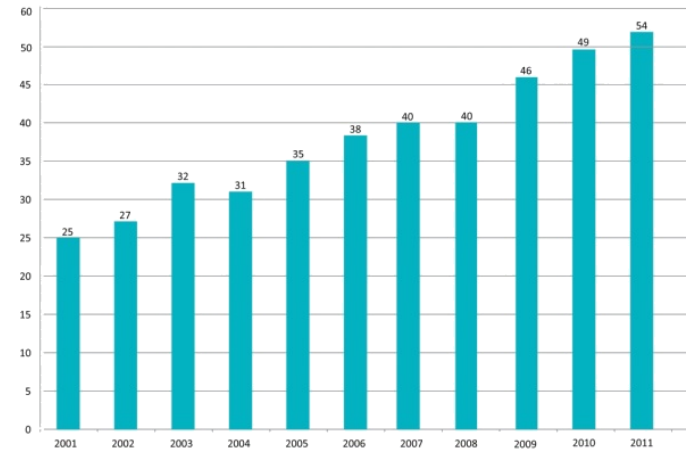

Figure A.2. FFRC staff numbers 2001-2011

Source: FFRC website, available at: http://ffrc.utu.fi/en/about/figures

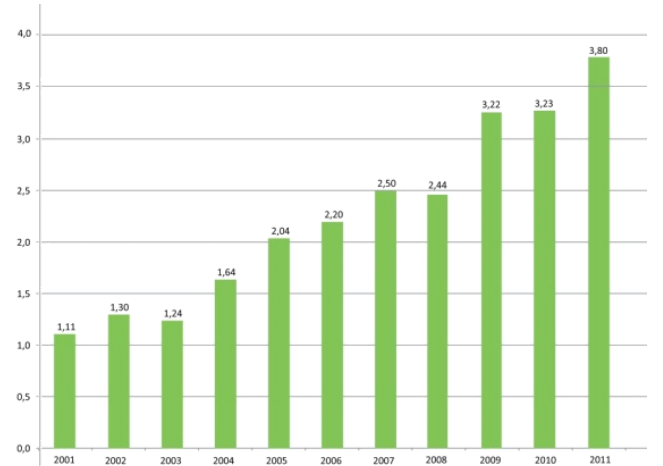

Figure A.3. Turnover of the FFRC 2001-2011

Source: FFRC website, available at: http://ffrc.utu.fi/en/about/figures 


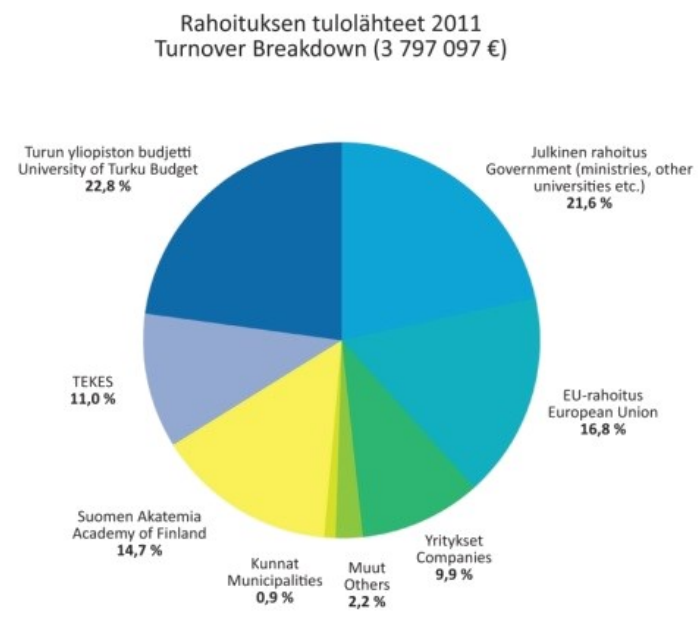

Figure A.4. Breakdown of FFRC's Turnover in 2011

Source: FFRC website, available at: http://ffrc.utu.fi/en/about/figures 